\title{
Conflict and Fieldwork
}

\author{
Zoltán Nagy \\ University of Pécs, Department of European Ethnology and Cultural Anthropology, Pécs
}

"Not everyone can fall

Like an apple at a stranger's feet"1

\begin{abstract}
In the first part of this study, I will take into consideration the possible relationships between the anthropologist and the subjects being researched with regards to the terms informant, friendship and cooperation, focusing on the possible connections between them and their impacts. It seems obvious that the relationship between the anthropologist and locals can only function if mutual trust develops in an atmosphere that enables research subjects to reveal themselves and the researcher to collect information effectively. It would seem that the prerequisite for this on the part of the researcher is friendliness, but this gives rise to the question of whether friendliness and positive relations are the only elements necessary for the research to be successful. In other words, is it possible to imagine that fieldwork can sometimes benefit from a lack of friendly behaviour? Is it plausible that occasional conflict between the anthropologist and locals or local individuals may facilitate effective research and assimilation? Using an event from my own fieldwork, I will attempt to show how conflict in a given situation can be decidedly constructive to the researcher and how in certain cases unplanned and spontaneous contact that crosses the line of self-censorship toward deliberate confrontation can be significant with regards to the success of the research.
\end{abstract}

Keywords: fieldwork methods, fieldwork ethics, conflict management, Siberia, Khanty

Not only is friendship a prominent research topic for anthropologists, but also a decisive metaphor of fieldwork. It is a term that is often used to embrace the concept of fieldworkcontacts. Friendships are often implied in anthropological works, and the anthropological studies are often dedicated to specific friends, almost as if it were a requirement to express gratitude to them. In spite of this, the true nature of the given friendship is

\footnotetext{
${ }^{1}$ Sergey Aleksandrovich Yesenin: Hooligan’s Confession. Translated by Lyuba Coffey.
} 
rarely discernible in the texts themselves, and usage of the term in fact conceals more than it reveals about the actual features of the friendship between researchers and interlocutors. Moreover, it is difficult to assess whether these relationships are to be regarded as friendships in the local or the Euro-Atlantic sense of the term. (BEER 2001) Interpreting the contact between the researcher and the researched subject as friendship can result in attempts to completely dismantle the hierarchical relationship between the two, making the local contact the co-author of a polyphonic anthropological work; ${ }^{2}$ or the relationship itself becomes one of the most important threads in the anthropological narrative (RABINOW 1977).

At the same time, the relationship between the researcher and the subjects under research can by no means be interpreted as merely a friendship e.g. the term is incompatible with the concept of informant as used in classical ethnographies. The term informant implies hierarchy; it is utilitarian and objectifies, defining the interlocutor as a source of data with whom the researcher is free to use any one of numerous methods to obtain the desired information (HÁLA 1997), meaning that the subject's manifestations as a private individuals must be kept in check if possible. It is not by accident that the term data source has increasingly become deemed as inappropriate in Hungarian ethnographic scholarship (NIEDERMÜLLER 1994:99) and that the term friendship, which has entirely different connotations, is now used to describe the nature of contact between interlocutors, who are often explicitly referred to as "my friends". ${ }^{3}$ Use of the term friendship emphasizes the individuality of the participants and personalizes them, going beyond the pragmatic aspect of the contact to focus on the emotional, human side of the relationship. This suggests a symmetrical relationship, whereas the ideology of friendship often serves to conceal what is actually a hierarchical relationship (DRIESSEN 1998) i.e. in the classic sense, fieldwork entails a researcher who determines the aim of the research, the methods used, the analysis of the obtained information and how the results are used.

In order to understand the relationships that develop in the course of fieldwork, it is perhaps even more important to separate the terms friendship and cooperation (rapport). It is frequently difficult to do so, and there are those who use them as synonyms. According to Corrine Glesne, friendship denotes a relationship built on affection and trust; our friend is a person in whose company we feel comfortable (GLESNE 1989:46). On the other hand, cooperation is also a relationship built on harmony, adaptation and agreement, but without the aforementioned close emotional contact, the key word being trust, which is the basis for cooperation between the researcher and the researched. In cooperation, it is the researcher's intentions and aims that are decisive. Research focuses on acquisition, in which cooperation is merely a tool, primarily used by the researcher. This, and the fact that the researcher always has the opportunity to withdraw, makes the

\footnotetext{
2 An extremely interesting attempt at this is Liria and Paloma's mutual text (DE LA CruZ - GAY Y BLASCO 2012), but this example also shows the limited validity of the approach: the co-written study follows the authors' relationship to one another instead of dealing with professional issues. Moreover, hierarchy cannot disappear entirely either since the final editor is the anthropologist, who is unable to under-emphasize his/her professional role.

${ }^{3}$ My argument can only be interpreted in the context of long-term fieldwork. In the case of brief expeditions, there is no alternative to the researcher-data source relationship.
} 
relationship asymmetrical, whereas friendship ideally should be symmetrical, at least according to Aristotle (ARISTOTLE 1999:142); it can only be called a friendship if the relationship is mutual. ${ }^{4}$

Apparently, cooperation is primarily a utilitarian concept, but friendship is usually not. It must be seen, however, that friendship is actually nothing more than a tool of anthropological fieldwork, an accessory ${ }^{5}$ that makes it possible for anthropologists to access information they would not be able to acquire with other methods. ${ }^{6}$ Hendry refers to this as the fieldwork-friendship paradox (HENDRY 1992), meaning a utilitarian relationship in which the divergent interests and expectations of the researcher and the subject make it impossible for either party to forge a true friendship (NAPLES 2003:39-40); or at the very least leads to role confusion (Compare: FrIEDMAN 1976; REINA 1959). Even so, it should be acknowledged that in this relationship it is not only the anthropologist who sees the friendship as utilitarian since research subjects also use the researcher as a means to achieve their personal aims: to raise their prestige (BoRSÁNYI 1992), as a mouthpiece to convey their message ${ }^{7}$ to local administrators ${ }^{8}$, not to mention the fact that said relationship may also involve direct financial compensation. ${ }^{9}$ Utilitarian considerations therefore can also be among the intentions of both parties in the relationship between the anthropologist and locals, but this in itself does not rule out the development of friendship, just as the relationship between two Europeans cannot be regarded as strictly utilitarian either. Among the three types of friendship in the classic sense as defined by Aristotle, one is a utilitarian relationship in which both parties expect benefits from one another i.e. someone can be friend because they are useful to us (Aristotle 1999).

The concept of utilitarianism therefore does not help to separate friendship from cooperation since both relationships may contain personal considerations that drive the intentions of the parties involved. Although friends calculate one another's behaviour just as the parties involved in cooperation do, the difference, according to Glesne, is that friendship is not accompanied by the constant vigilance, alertness and lack of liberty so typical of cooperation (GLESNE 1989:46).

The concept of trust and affection may help us to more precisely define friendship and cooperation. The relationship between cooperating parties cannot function without mutual trust, making the work itself impossible as well. The researcher hopes that the subjects will honestly reveal their beliefs and emotions without concealing much and without distortion whereas the subjects hope that the researcher will not do harm to

\footnotetext{
${ }^{4}$ Today, however, the concept of friendship is not necessarily considered to be a symmetrical relationship. (Compare: FELD 1991)

${ }^{5}$ Even Malinowski writes that one must settle among the indigenous people because then there is no opportunity for other company and one must rely on the forced-company of locals to avoid loneliness as well. (MALINOWSKI 1992:6-7)

${ }^{6}$ Regarding friendship as a tool for obtaining confidential information. See: UHL 1991.

${ }^{7}$ For a unique interpretation, see: Schmidt, 2001. About the intentions of the researcher, See also: NAGY 2011.

${ }^{8}$ I often accompanied my Khanty acquaintances to the local council, where they simply needed my presence to add weight to their requests. It was in this way, for example, that my new host's family was granted a new house by the local government.

${ }^{9}$ This is true for the anthropologist as well since whatever the relationship may be, they are helping us to create an existence and to build the foundation of our professional career.
} 
them by taking advantage of their self-revelation. This type of relationship is built on trust, although not necessarily on affection. Researchers are also able to learn from and successfully work together with subjects who they are not fond of at all: the quality of information gained in the course of fieldwork does not necessarily depend on the type of relationship that exists between the two parties. In contrast, while friendship is also built on trust, it also means a close emotional bond. Both parties are more deeply involved in the relationship and are willing to do things for one another that are not expected in a cooperative relationship (GLESNE 1989:46-47).

Both types of relationship carry their own practical benefits as well as ethical risks. Friendship may even have a negative impact on the outcome of the research. The partiality of the researcher towards their key source and friend - even on an unconscious level - inherently carries with it the likelihood of distorting the sample. The tight bond that develops between the two parties can prevent the researcher from gaining access to other groups within the studied community; and the research subject may even overidentify with the anthropologist, leading to exaggerated behaviour in attempts to satisfy their expectations. On the other hand, in the consciously "feigned friendship" typical of cooperation (DUNCOMBE - JESSOP 2002) the research subjects may misunderstand the anthropologist's search for connection and overvalue it, becoming vulnerable to their own unfulfilled expectations, causing conflict. This said, it is also possible that the researcher is already using the cooperation as a mask, consciously manipulating and taking advantage of the subject, although this exploitation could also be mutual (GLESNE 1989:48-52).

However we assess the two relationships, since the established bonds are goaloriented with the aim of successful research, anthropologists conducting fieldwork try to behave in such a way as to build sympathy and trust in their partners in order to create an atmosphere that enables the subjects to reveal themselves and the researcher to collect information effectively. Whether we are friends or merely cooperating partners, it would seem that the only possible behaviour that can be expected from the researcher is friendliness, which is why we do not even consider the assumption that there may be other ways to conduct fieldwork. In this case, I am not primarily thinking about roles that the anthropologist has to/must find, which are viable and acceptable to both parties, but about whether positive relations are the only prerequisite for successful research or not. In other words, can a lack of friendly behaviour sometimes facilitate effective fieldwork? Of course we know that locals can even be hostile, ${ }^{10}$ but can the anthropologist also be hostile? Posed differently, the question is the following: if the anthropologist enters into conflict with locals or local individuals, does this unequivocally destroy the possibility of fieldwork, or is it viable to assume that it may in fact foster assimilation and effective research? In the rest of this article, I will use a personal example in search of an answer to this question. ${ }^{11}$

In order to help the reader understand the story, I must first explain a host of things in connection with my own fieldwork, and so it will take time to address the actual

\footnotetext{
${ }^{10}$ For a flexible interpretation, see: Napoleon Chagnon's highly contested work. (CHAGNON 2013)

${ }^{11}$ The question addressed in the study is a continued reflection on a discussion I had with Bea Vidacs. The input of the following individuals was of tremendous assistance in writing it: Judit Balatonyi, Csaba Mészáros and Gábor Vargyas, in addition to my written correspondence with Veronika Murányi and Tünde Komáromi.
} 
situation. Since I must also stick to the question posed, my interpretation may sometimes be lacking as many issues may arise that I can no longer even recall, much less evaluate. In addition, there are also details that I feel must be suppressed.

During my second visit to the Khanty people living along the Vasyugan River in Siberia, one of my Khanty acquaintances died on January 21, 1999. In the course of my research at the time, I wanted to focus on a single village in keeping with the classic fieldwork approach. My chosen site was Ozernoye, where there were no longer any permanent residents living at the time, it being on the outskirts of Novy Vasyugan, approximately 40 kilometres away. Pavel, the person who died that day, regularly visited Ozernoye and spent most of his time there with his wife, who had lived there her entire life. For this reason, I made their acquaintance early on. They were among my closest contacts, and we met on a regular basis. Due to our personal relationship, Pavel's death had an emotional impact on me, and I was actively involved in his funeral arrangements, in which my host Petro, who was Pavel's brother-in-law, played a serious role.

There were many problems surrounding the funeral. ${ }^{12}$ The circumstances of Pavel's death were not exactly clear either, and they remain unclear to this day. It is known that his death was preceded by several days of drunkenness. Pavel and his son had acquired an exceptionally large amount of money as a result of their hunting spoils, after which Pavel took out his pension as well, followed by a drinking binge in which the men drank away most of the money. The most accepted explanation - as recounted by witnesses present at the time of death - was that after he drank the last water-glass full of vodka, Pavel rose, asked his wife if there was water in the wash-basin, then washed his hands, lay down on the floor and stayed that way: his heart could no longer take the stress. Other versions placed the blame on the quality of the vodka or claimed that a scuffle had occurred prior to his death. As the entire family was heavily inebriated, none of them noticed that Pavel had died and only faced the situation that evening when, for other reasons that shall remain undisclosed, they were questioned by the police.

The funeral arrangements were made by distant relatives in keeping with local norms, but a significant majority of the locals were in uproar over the fact that Pavel's family would not even have been able to carry out the task at all due to their level of intoxication. In addition to their being practically useless, their financial circumstances also prevented them from making the arrangements: they had no savings and were living from day to day. This is why it was me who contributed a significant sum towards covering the funeral costs, in light of my close personal relationship to Pavel.

Being asked by acquaintances and even strangers for smaller-larger sums of money had already been a natural part of my fieldwork. Presumably, this was a compulsory prerequisite; the anthropologist - or any other outsider for that matter - was considered by locals to be a potential source of money, especially in fieldwork locations where very little money flowed in the community. Until then, the singular aim of these regular requests had been to obtain vodka, regardless of the cover story that generally accompanied them. I was also clear about the rules of the game; borrowing money for vodka was a frequent and basically accepted approach, even though everyone involved knew there was very little likelihood that the loan would ever be repaid. I tried to maintain balance in such situations

${ }^{12}$ For a detailed analysis of the funeral, see: NAGY 2007:246-258. 
so that I would not empty my wallet too soon and still avoid becoming isolated or being accused of miserliness, which was an especially negative category (even there). Actually, the sums requested were generally small, enough for one or two glasses of vodka.

In comparison to the above, the amount I contributed to the funeral was exceptionally high and the news spread rapidly throughout the village. My respect grew, as did the number of people who were jealous of me. My increase in status was reinforced all the more by the fact that I actively took part in the funeral arrangements as well as the funeral itself. The funeral undoubtedly contributed to the growing number of people who became acquainted with me, accepted me and supported my presence.

In this virtually ideal situation, my host's wife, Anisa Egorovna, returned only four days after the funeral, having previously having been absent for more than a month. She had travelled to Tomsk for medical examinations, but had fallen ill and was kept in hospital for three weeks. Anisa Egorovna was a woman of strong character ${ }^{13}$ and upon her arrival immediately took control of the events. She forcefully inquired why I had given money for the funeral and vowed that she would have the money repaid. ${ }^{14}$ When I decisively rejected her vow, we had a heated debate as to what should be done about the money. In the midst of our argument, Anisa Egorovna angrily asked why I constantly felt the need to help people and declared that I should finally start acting like a man. When I reasoned that masculinity was not synonymous with a lack of empathy, she practically ignored me.

Two things should be known in order to understand this situation. One is that Khanty society, and that of the local Vasyugan community even more so, as well as Russian society in general, is deeply entrenched in a cult of masculinity. Men are generally expected to be hard, combative, confrontational, aggressive - espousing military virtues. Masculinity and the cult of power ${ }^{15}$ are complex issues in Russian society, which I have no opportunity to discuss here, but which I nevertheless had to face on a daily basis. At the time, I had thought that any kind of aggression was incompatible with my ideal concept of fieldwork and would certainly not facilitate my work at all. I tried to adapt as much as possible, avoiding conflict whenever I could. This was not difficult for me as I regarded myself as a peaceful individual in my private life as well, always striving to solve argumentative situations through compromise. When I put together the pieces of the mosaic in retrospect, I realized that this attitude was incomprehensible, strange and perhaps even disturbing to locals. In any case, my behaviour was by no means in keeping with the local principle of masculinity ${ }^{16}$ In the course of a much earlier conversation, Anisa Egorovna had actually claimed that I was exactly like the saints depicted on icons: "Your face is just as long, your

\footnotetext{
${ }^{13}$ Regarding strong Siberian women, See: Ssorin-Chaikov 2003, or MészÁros 2013. The contrast between the local ideal of masculinity and that of strong women is only illusory; they actually reinforce one another.

${ }^{14}$ I sought Petro's opinion in advance of my loan, and he supported my idea. In terms of help within the family, Petro and Anisa Egorovna's relationship diverged significantly and had also led to conflict between them in the past. (See: NAGY 2000:301-302)

${ }^{15}$ This is usually in connection with combativeness and military virtues during wartime.

${ }^{16}$ Regarding Soviet and post-Soviet attitudes about masculinity, See: UsHaKIN 2002 and ZDRAVOMYSLOVA 2000 .
} 
nose is just as big, and you're just as delicate and soft." The schemtization of masculinity in our debate can be traced back to this difference in norms.

On the other hand, it is also important to understand the basis on which Anisa Egorovna thought she had the right to interfere in my affairs at all. I had met the family in 1992, under very unusual circumstances. Prior to my fieldwork trip, I had already met Petro's daughter Tanya in Tomsk, where she was a secretary at the Institute of Northern Languages and Peoples. I was travelling to the fieldwork site with a linguist on a classic expedition financed by the local university, and we took Petro and Anisa Egorovna's daughter with us as well. Tanya's trip home was covered by the university, which was a tremendous help in light of the financial circumstances at the time. Accordingly, when we arrived at the site, we were immediately treated as honoured guests of the family, who not only felt obligated because Tanya's trip had been funded, but also because Tanya had been offered a job at the university, which also meant that she had an opportunity to apply. This distinguished role had many consequences. On one hand, it created an excellent research situation since respected guests are to be helped and treated well by everyone. However, this also meant that I would not have an opportunity to move in with another family when staying in Novi Vasyugan without causing offense and scandal - even thought I had no intention of doing so. Thirdly, since I was approximately the same age as Tanya, people increasingly began to interpret our relationship as a familial one. They regularly referred to us as "the boys" and spoke to me about Tanya as if she were my sibling. In fact, half of the village began to talk about me as a relative. Anisa Egorovna was fond of telling neighbors and more distant acquaintances that I was her son from her first marriage who had moved far away to the $\mathrm{West}^{17}$, but there was also a time when I was introduced to another acquaintance as Tanya's husband. Obviously, this was also due to the fact that I had developed a close and affectionate relationship with the family over a short period of time. In spite of her difficult nature, I was fond of Anisa Egorovna and accepted her, but an even closer bond developed between Petro and I, and I know that these feelings were mutual. This family-like relationship was the reason why Anisa Egorovna felt she had the right to become involved in my affairs, defending my interests like a protective mother, even if it meant opposing me.

So it was that in spite of my repeated protests, Anisa Egorovna decided that she would have my expenses reimbursed, especially the sum I had contributed to the funeral. She tried to do so in a variety of ways. First, she attempted to convince the local council to pay back the amount to me since the council commonly granted aid for funerals. The aid was actually paid to Pavel's family, but they drank it all away again and I never received any of it. She also tried putting direct pressure on people she knew were in debt to me, asking them to repay me and even threatening them regularly. She also tried indirect means: she began spreading a rumour around the village that she had made of

\footnotetext{
${ }^{17}$ This is how the historical linguistic separation comparison became a metaphor for my personal life and how I became the single representative of migrating Ugrians. Thanks to public education, everyone had some concept of the Finno-Ugric language relation itself.
} 
list of individuals who owed me money and had submitted it to the police and to the council, and that these authorities would be coming to collect the money. ${ }^{18}$

Taking all of this into consideration, it can be said that my situation in Novi Vasyugan following the funeral was positive in a way that an anthropologist in the field could never have imagined in their wildest dreams. In the weeks that followed, however, my presence became equally problematic for many and led to conflicts. It was at this point that I grabbed at an opportunity to visit the county seat for a week to do research at the local archive.

The situation escalated upon my return. Because of my trip to the archives, I had missed the burial commemoration on the $40^{\text {th }}$ day after Pavel's death, but I had also missed the $9^{\text {th }}$ because we had spent weeks in the taiga following the funeral; hunting season was in progress. I found out that the burial-feasts had not taken place without debate. I should add that there had already been conflicts at the funeral as well. The feast following the burial was not characterized by reserved behaviour either. Vodka flowed freely, which raised spirits and laughter at first, but then led to serious arguments and physical confrontation. One of the organizers sent guests home in a drunken stupor, and this almost led to a fight. The subsequent commemorations were no less intense. Based on recollections, fights had broken out during both the $9^{\text {th }}$ and the $40^{\text {th }}$ feasts. During the first one, the drunken widow chased the organizer's nephew out of the house while continuously pounding on him, and during the second she slapped his nephew.

It was the last feast that raised the strongest reaction. On this occasion, the deceased's daughter, Natasha, was also participating. Natasha lived in Kiev, in a city and in a different county, which always put her in the focus of attention. She clearly enjoyed this attention, and all of her gestures implied that she had "risen up from the scum". She constantly emphasized her university education ${ }^{19}$ and made of point of never speaking Khanty, whereas she had spoken her mother tongue fluently as a child. At the same time, she regularly flaunted her knowledge of foreign languages and boasted about how many she could speak. Language was an important tool of her identity, and she spoke affectedly in Russian as well. The locals were clearly aware of this and understood that she was using language to build her self-image; and they quoted her use of foreign words and her affectations with no small amount of malice.

While Natasha always claimed that she lived a wealthy life in the Ukraine, she strove to spend as little as possible on the feasts, buying everything at the cheapest price and in the smallest quantities. In addition, the celebration ended in an extremely embarrassing way because nobody wanted to re-store the leftovers from the dinner a second time. Naturally, all of this was judged in a negative light by the village and it was a constant subject of conversation that the family was entirely unfit to behave in accordance with

\footnotetext{
${ }^{18}$ There is also the possibility that he was actually defending his own interests since every sum of money invested elsewhere would be short-changing his own family, but Anisa Egorovna always made sure that our relationship was not one based on business. She never requested money for anything and even had difficulty accepting gifts. In my opinion, this was due to my role as a "fond guest". At the same time, this was partly a performance in which we both knew that I was obligated to return their assistance.

${ }^{19}$ She had obtained her degree in Leningrad, at what was then referred to as the Herzen College, where she was accepted as part of the quota favouring northern ethnic minorities.
} 
the norms expected in connection with a case of death; their hospitality was inappropriate and they sent their guests packing, which meant they were bad hosts. Due to Natasha's presence, it was constantly added to the story that for all of the aforementioned reasons, neither Natasha nor her family had any right to feel that they were superior to anyone else.

Thus, vain Natasha's pride was wounded. She was extremely upset that a foreigner had paid for her father's funeral. Moreover, during my absence, Anisa Egorovna had tried every means at her disposal to demand the money back. I can safely say therefore that despite having never met be before, Natasha was not fond of me. Her revulsion was even further amplified by the fact that a local journalist had just published a long article about me, my fieldwork and the Khanty in the weekend supplement of the local newspaper. Although the article shed everyone in a positive light, he took advantage of our personal conversation and against my intentions added a short postscript expressing his sorrow that one of my Khanty acquaintances had just passed away, clearly due to vodka. Naturally, this burdened my relationship with Pavel's family, even though the journalist had made amends at my explicit request. ${ }^{20}$

After all of this, I received news that Pavel's family was expecting me because they wanted to settle their debt. I immediately visited them and assured them throughout my stay that I had no regrets about giving them the money and that there was no need to repay it. They behaved distantly with me from the very start, and the atmosphere was decidedly hostile; the tension in the air was tangible due to Natasha's wounded vanity, the shame and anger they felt in connection with their debt and because of the truly offensive newspaper report. Although I stayed for a long time, I was unable to ease the conflict. As with the burial feasts, more and more vodka was consumed and the conversation became increasingly heated. Eventually, one of the men present, who did not even belong to the immediate family, aggressively attacked me following a verbal spat, and in the heated scuffle that followed I defended myself ${ }^{21}$ and slammed the door on them.

I regretted then, and still do today, that the situation escalated to the point that it did, although I still believe I had no choice but to act in the way that I did. I sensed and later learned for certain that the incident had caused a major uproar and had become the primary topic of gossip among the locals. Hence, I firmly believed that my fieldwork had come to an end and that I would never have the opportunity to continue it, all doors having been slammed in front of me. Nevertheless, long before this particular conflict, I had already arranged to transfer my research headquarters to the Yugan River, and now this seemed an appropriate occasion to extract myself from the situation. Feeling relieved, I set out for my new fieldwork site a few days later.

Today I am aware that this was a huge mistake. I quickly had to realize that whatever had happened, I was bound to the Vasyugan with every fibre of my being. While I was

\footnotetext{
${ }^{20}$ In reality, he merely acted in the same way as the anthropologist: utilising, but not taking advantage of the acquired information, yet not always knowing whether the information was consciously meant to be public or something that had been shared confidentially.

${ }^{21}$ I am aware that my heated reaction was obviously motivated by the tension that Anisa Egorovna deliberately flamed between us with regards to the money, but the conflict that I had experience in the home of my host, in my immediate environment, the day before certainly contributed to it: the mother-daughter confrontation that broke out because of Tanya's drunkenness ended in Tanya's unsuccessful attempt to commit suicide.
} 
trying to create contacts at the new site, I was constantly thinking about my Vasyugan acquaintances, with whom I had established a strong emotional bond; and while I was stalking the forest with young hunters near the Yugan, in the evenings I was pondering issues that had arisen during my time along the Vasyugan. Recognising the absurdity of the situation, I returned to the Vasyugan region in three weeks' time, excited about whether I could return at all and wondering how I would be greeted there.

To my greatest surprise, my arrival was not problematic in the least. As a matter of fact, I think that I was in a better situation than I had been in before. There is no doubt that the mere fact of my return played a huge role in this. Understandably, locals felt that my trip to the Yugan River meant that I did not deem their lives to be interesting enough to stay. They had already bid farewell to me by telling me that I should be expecting a very archaic way of life there, with "authentic" Khanty who lived in forest dwellings. They were of the opinion that this must be far more interesting to an ethnographer, yet continuously expressed worry about me and about them. ${ }^{22}$ Anisa Egorovna had let me depart for the Yugan region, which was considered to be barbaric, expressing the same concern as my mother had when I was preparing for my trip to the Vasyugan. My return and the fact that I told locals I felt more comfortable there made them appreciate their own lives all the more. They reflected intensely and emotionally on my inability to break ties with them and that I had returned to them as opposed to merely searching for "Khanty", so to speak.

The role that my return played in the development of this snug relationship could be discussed in far greater detail, ${ }^{23}$ but more importantly, I discovered that locals were also continuously reflecting on the conflict that had taken place before my departure. Depending on their individual temperament, some felt sorry for me while others expressed concern or bemusement, emphasising what a good little adventure it had been for me; and others tried to re-ignite the conflict. In any case, everyone agreed that I had stood up for myself in the situation and had shown that I was a real man, taking on the conflict in keeping with the masculine norms expected of me. That is to say that the events had no negative impact on my continued fieldwork.

I know today that I was mistaken in presuming that aggressive behaviour (or a corresponding reaction) would ruin my contacts. It was precisely this fieldwork - and the impact of this conflict - which made me recognize that when aggression is associated with alcohol consumption, locals tend to reinterpret it: they either absolve the aggressors as victims of alcohol or overemphasize the comic nature of the incidents and create anecdotes about them. ${ }^{24}$ It is also important to note that violence and aggression are by no means unacceptable in Siberian society, being a "socially constructed mode of behaviour." (MÉsZÁRos 2013:207), or as in this particular case: "It might be more expedient to interpret aggression as a behavioural strategy for solving certain conflicts." (MÉSZÁros 2013:207)

\footnotetext{
${ }^{22}$ Regarding the relationship between locals and the Khanty in the Yugan region, See: NAGY 2002.

${ }^{23}$ For a unique perspective on the importance of being on site and the issues that arise in connection with repeated returns, see: MuRÁnYI 2017.

${ }^{24}$ NAGY 2000; regarding the connection between alcohol and violence, see also: MÉszÁros 2013:208-209.
} 
Therefore, to my greatest amazement, instead of having a negative impact on me or my fieldwork, the intense conflict and the subsequent fight actually made me more comprehensible and human in the eyes of locals. I became just one of their men, stepping out of the icon, so to speak, to be among them. Admittedly, my relationship with Pavel's immediate family was never the same again, but even the man I had brawled with gave me a friendly pat on the back and told me that may decision to return was a good one, chuckling about what a hoot our previous little encounter had been.

Taking all of the above into consideration, it can be said that rather than destroying my identity as a researcher as I had previously expected, the aforementioned conflict actually elevated my status from one that was incomprehensible and strange to locals to one that was in keeping with the behavioural norms familiar to them. It not only strengthened the emotional bond between us - with the exception of Pavel's family - but facilitated my fieldwork even more. It would not be appropriate to interpret this change as a simple threshold which took me from being a "wisp of wind" to my existing status ${ }^{25}$ because this process is not singular, not one-directional and does not apply to the same degree in the case of various individuals. It remains certain, however, that from this point on I was treated far more positively and naturally by the majority of locals. Although the incident is a painful memory for me and one that I am not proud of at all, the topic has been recalled on numerous occasions with every new fieldwork visit to the Vasyugan and has always created an insider aura around me that reduces the distance between myself and the locals. Obviously, this not only has to do with the specific conflict itself, but also with divergent interpretations of the term conflict.

There is no denying that my own behaviour during my fieldwork changed as well. Reflecting upon the situation, which developed by accident and completely unintentionally, I took on the masculine norms and behaviour that locals expect, boldly voicing my differing opinions and protecting my interests more decisively. I was no longer concerned that conflicting views would threaten my relationship with them.

I do not fully agree with the Thomas Hylland Eriksen's assessment on the role of friendships during fieldwork "At the end of the day, the value of participant observation lies in the quality of the empirical data one has collected, not in the number of close friends one has acquired in the field". (ERIKSEN 2001:27) In my opinion, ethical aspects cannot be subordinated to scientific considerations in the assessment of fieldwork, but in light of my own case, I had to concede that friendship and rapport are not the only tokens of success in fieldwork. Friendship is a rare gift, in the field as well as at home. The most important thing to do is to create viable relationships with the majority of people in order to make the research possible.

Fieldwork involves various types of contact with locals. Identical behaviour and identical relationships cannot be expected from everyone. Locals cannot behave identically either, and nor can we feel the same about every individual. In spite of the utilitarian - mutually utilitarian - background expectations, sincere friendships can be formed, as in the case of Petro, for example, but there can also be balanced and accepting cooperative relationships as well as well as cold ones, like the one with Pavel's family, or

${ }^{25}$ Regarding this, See: Geertz's legendary parabola recounting their own "welcome" in Bali (GeERTZ 1994), and a critical analysis (CRAPANZANO 1992.) 
even hostile ones, like the one between Natasha and myself. In reality, these relationships are no different from the ones the anthropologist has at home.

As to how such relationships can be formed, methodological literature states that it is not only our own intentions that can have an impact, but also the attitudes and cultural models of local society. (GLESNE 1989:48) According to this view, in the interest of developing cooperation, researchers in the field must occasionally do things that are at odds with their own intentions or cultural norms, but which correspond to local behavioural norms and expectations. ${ }^{26}$ Even so, it cannot be denied that the situation of the anthropologist working in the field is basically a stressful one, often a lonely endeavour in which the researcher is yearning for real relationships instead of the his/her role as "marginally indigenous". (FreILICH 1977) This may put them off their normal behaviour: "At times, field researchers feel the need to act as a humans because the role they are forced to play does not satisfy that need." (GLESNE 1989:48) This example demostrates to me that instead of a strategically balanced and uniformly friendly approach to everyone, in some cases unplanned and spontaneous contact that crosses the line of self-censorship toward deliberate confrontation can be far more important concerning the success of the research.

\section{REFERENCES CITED}

Aristotle

1999 Nicomachean ethics. Translated by W. D. Ross. Kitchener: Batoche Books. BEER, Bettina

2001 Anthropology of Friendship. In Smelser, Neil J. - Baltes. Paul B. (eds.) International Encyclopedia of the Social \& Behavioral Sciences, 5805-5808. Michigan: Elsevier.

BORSÁNYI, László

1992 A néprajzi interjú. Átmenetek. A mindennapi élet antropológiája 3 [Ethnologic interview: Transitions. The Anthropology of Daily Life], 5-6:93-100.

Chagnon, Napoleon A.

2013 Noble Savages. My Life among Two Dangerous Tribes: the Yanomamö and the Anthropologists. New York - London - Toronto - Sidney - New Delhi: Simon \& Schuster.

Crapanzano, Vincent

1992 Hermes'Dilemma and Hamlet's Desire: On the Epistemology of Interpretation. Cambridge: Harvard University Press.

De La Cruz, Liria - Gay Y Blasco, Paloma

2012 Friendship, anthropology. Anthropology and Humanism 37:1-14.

DRIESSEN, Henk

1998 Romancing Rapport: The Ideology of 'Friendship' in the Field. Folk 40:123-136.

${ }^{26}$ Behaviours divergent from our own models, See: Pettigrew 1981; complicated relationships due to the simultaneous presence of various models, See: Toulouze 2014. 
Duncombe, Jean - Jessop, Julie

2002 'Doing Rapport' and the Ethics of 'Faking Friendship'. In Miller, Tina Birch, Maxine - Mauthner, Melanie - Jessop, Julie (eds.) Ethics in Qualitative Research, 108-122. London: Sage Publications. http://study.sagepub.com/ sites/default/files/Duncombe\%20\%26\%20Jessop.pdf (accessed February 4, 2017)

ERIKSEN, Thomas Hylland

2001 Small Plaxes, Large Issues. An Introduction to Social and Cultural Anthropology. London: Pluto Press.

FELD, Scott L.

1991 Why your friends have more friends than You? The American Journal of Sociology 96(6):1464-1477.

FREILICH, Morris

1977 Marginal natives at work. New York: John Wiley \& Son.

FrIEDMAN Hansen J.

1976 The Anthropologist in the Field: Scientist, friend, and voyeur. In RYNKIEWICH, Michael Allen - Spradley, James P. (eds.) Ethics and Anthropology. Dilemmas in Fieldwork, 123-134. New York: Wiley.

GeErTz, Clifford

1972 Deep Play: Notes on the Balinese Cockfight. Daedalus 101(1):1-37.

Glesne, Corrine,

1989 Rapport and friendship in ethnographic research. Qualitative Studies in Education 2(1):45-54.

HÁLA, József

1997 Hogyan gyüjtöttek elődeink? Anekdoták és történetek a magyar néprajztudomány klasszikusairól [How Our Predecessors Collected. Anecdotes about the Classics in Hungarian Ethnography]. In Csoma, Zsigmond - VIGA, Gyula (eds.) Európából Európába. Tanulmányok a 80 esztendös Balassa Iván tiszteletére, 585-601. Budapest - Debrecen: Györffy István Néprajzi Egyesület.

HENDRY, Joy

1992 The Paradox of Friendship in the Field: Analysis of a Long-Term AngloJapanese Relationship. In OKely, Judith - CAllaway, Helen (eds.) Anthropology and Autobiography, 161-171. London: Routledge.

MaLinowski, Bronislaw

1992 Argonauts of the Western-Pacific. An Account of Native Enterprise and Adventure in the Archipelagoes of Melanesian New Guinea. London: Routledge.

MÉszÁros, Csaba

2013 Tekintély és bizalom. Kultúra és társadalom két szibériai faluközösségben [Respect and Trust, Culture and Society in Two Siberian Villages]. Budapest: PTE BTK Néprajz - Kulturális Antropológia Tanszék, MTA BTK Néprajztudományi Kutatóintézet, L’Harmattan.

MurÁNYI, Veronika

2017 Kalibatörténet. Nyomozati szakaszok a megértésben [A Cabin Story: Investigative Phases in Understanding]. Antro-pólus 2(1):199-213. 
NAGY, Zoltán

2000 "Fél méterrel repülni a föld felett". A vodka a vaszjugáni hantik kultúrájában [Flying above the Ground. Vodka in the Culture of the Khanty People in Vasyugan River Region]. Tabula 3(2):284-315.

2002 "Miféle hantik vagyunk mi?" A vaszjugáni hantik és a világ [What Kind of Khanty Are We? The Khanty of Vasyugan and the World.] In Pócs, Éva (ed.) Közösség és identitás. Studia Ethnologica Hungarica III, 33-77. Budapest: L'Harmattan - PTE Néprajz Tanszék.

2007 Az öseink még hittek az ördögökben. Vallási változások a vaszjugani hantiknál [Our Ancestors Still Believed in the Devil. Religious Changes among the Khanty of Vasyugan]. Budapest: MTA Néprajzi Kutatóintézet, PTE BTK Néprajz - Kulturális Antropológia Tanszék, L’Harmattan.

2011 Ismertetés: Farkas, Judit: Ardzsúna dilemmája. Reszocializáció és legitimáció egy magyar Krisna-hívő közösségben [Arjuna's dilemma. Re-socialization and legitimization in a Hungarian Krishna community] Ethnographia 122:91-95.

NAPLes, Nancy A.

2003 Feminism and Method: Ethnography, Discourse Analysis, and Activist Research. New York: Routledge.

NiedermülLeR, Péter

1994 Paradigmák és esélyek, avagy a kultúrakutatás esélyei Kelet-Európában [Paradigms and Opportunities, Opportunities for Cultural Research in EasternEurope]. Replica 13-14:89-129.

Pettigrew, Joyce

1981 Reminiscences of Fieldwork among the Sikhs. In RoBerTs, Helen (eds.) Doing Feminist Research, 62-82. Boston: Routledge \& Kegan Paul.

RABINOw, Paul

1977 Reflections on Fieldwork in Morocco. Los Angeles - London: Berkeley University of California Press.

ReIna, Ruben E.

1959 Two Patterns of Friendship in a Guatemalan Community. American

SCHMidT, Éva Anthropologist 61:44-50.

2001 Terepgondolatok az osztják nép és kutatása hőskoráról [Thoughts Concerning Fieldwork among the Ostyak People and Classic Research]. Népi kultúra-Népi Társadalom. A Magyar Tudományos Akadémia Néprajzi Kutatóintézetének Évkönyve XX. Etnológiai tanulmányok, 99-120. Budapest: Akadémiai.

Ssorin-Chaikov, Nikolai V.

2003 The Social Life of the State in Subarctic Siberia. Stanford: Stanford University Press.

Toulouze, Eva

2014 Femme sur le terrain: difficultés et défis dans la taïga de Sibérie occidentale. $=$ Slovo, Mélanges offerts à Anne-Victoire Charrin, 259-281. https://hal-inalco.

UhL, Sarah archives-ouvertes.fr/hal-01275687/document (accessed January 28, 2017).

1991 Forbidden Friends: Cultural Veils of Female Friendship in Andalusia. American Ethnologist 18(1):90-105. 
USHAKIN, Serge

2002 O muzhe(N)stvennosti. Sbornik statei [On Masculinity. Collected essays]. Moskva: Novoe literaturnoe obozrenie.

ZDRAVOMYSLOVA, O.M.

2000 "Russkaia ideia": antinomiia zhenstvennosti i muzhestvennosti v natsionalnom obraze Rossii [The Russian Ideal. The Antinomy between Femininity and Masculinity in the National Image of Russia]. Obshchestvennye nauki $i$ sovremennost' 4:109-115.

Zoltán Nagy is a cultural anthropologist. He works as a professor and the Head of the Department at the University of Pécs (Department European Anthropology and Cultural Anthropology). He has conducted fieldwork in Western-Siberia in the Tomsk region among the Vasyugan Khanty people since 1992. He is interested in issues of identity, religion, landscape and the post-soviet period. E-mail: nagy.zoltan@pte.hu 